\title{
Konsentrasi Logam Berat Kadmium (CD) Pada Sedimen Di Daerah Sekitar Perairan Pelabuhan Kapal Barang Talumolo Kota Gorontalo
}

\author{
Sri Yuningsih Noor* \\ "Staf Pengajar Program Studi Perikanan dan Kelautan Universitas Gorontalo \\ E-mail : yuyun.noor@gmail.com
}

\begin{abstract}
The aim of this research was to determine the concentration cadmium (Cd) in the sediments in the area of Talumolo Cargo Ship Port, Gorontalo. The method used in this research was descriptive analysis as a mean of describing and explaining the result which has already been obtained then compare it with the quality standard set by The Department of Conservation and Natural Resources Melbourne (2004) and ant the quality standard set by Dutch Quality standars For Metals in Sedimen (IADC/CEDA, 1997). The results showed that the concentration cadmium (Cd) in the sediments in the area of Talumolo Cargo Ship Port, Gorontalo City, the highest was found at point 2 (the sediment in the harbor area) with the calculation reached $0.3229 \mathrm{ppm}$, and the second was found at the third point (sediment in the sea area) with $0.2225 \mathrm{ppm}$, while the lowest cadmium was in the first point (Bone estuary) with the number 0.2027 ppm. The concentrations of cadmium (Cd) in the sediments in the area of Talumolo Cargo Ship Port, Gorontalo still not reached the quality standard set by The Department of Conservation and Natural Resources Melbourne (2004) which was set as 1ppm, and the quality standar set up by the Dutch Quality Standars For Metals in Sediment, IADC/CEDA, (1997) which was $0.8 \mathrm{ppm}$.
\end{abstract}

Keywords : Heavy metals, Cadmium, Sediment, Talumolo, Gorontalo 


\section{Pendahuluan}

Wilayah pesisir didefinisikan sebagai daerah pertemuan antara daratan dan laut, ke arah darat merupakan wilayah daratan yang masih dipengaruhi oleh fenomena lautan, seperti gelombang, pasang surut, angin laut, dan lainlain, sedangkan ke arah laut merupakan wilayah laut yang masih dipengaruhi oleh aktivitas daratan seperti erosi, sedimentasi, dan lain-lain (Dahuri et al. 1996). Pada umumnya wilayah pesisir merupakan daerah yang rentan terhadap pencemaran akibat kesalahan dalam pengelolaannya karena menjadikan kawasan ini sebagai tempat pembuangan segala macam limbah yang berasal dari daratan oleh aktivitas manusia ke perairan laut. Wilayah pesisir didefinisikan sebagai daerah pertemuan antara daratan dan laut, ke arah darat merupakan wilayah daratan yang masih dipengaruhi oleh fenomena lautan, seperti gelombang, pasang surut, angin laut, dan lain-lain, sedangkan ke arah laut merupakan wilayah laut yang masih dipengaruhi oleh aktivitas daratan seperti erosi, sedimentasi, dan lain-lain (Dahuri et al. 1996).

Pada umumnya wilayah pesisir merupakan daerah yang rentan terhadap pencemaran akibat kesalahan dalam pengelolaannya karena menjadikan kawasan ini sebagai tempat pembuangan segala macam limbah yang berasal dari daratan oleh aktivitas manusia ke perairan laut. Menurut Nordic (2003) sumber-sumber logam berat $\mathrm{Cd}$ di laut, berasal dari sumber yang bersifat alami dari lapisan kulit bumi seperti masukan dari daerah pantai yang berasal dari sungai-sungai dan abrasipantai akibat aktivitas gelombang, masukan dari laut dalam yang berasal dari aktivitas geologi gunung berapi laut dalam, dan masukan dari udara yang berasal dari atmosfer sebagai partikel-partikel debu. Logam berat $\mathrm{Cd}$ juga dapat berasal dari aktifitas manusia, seperti limbah pasar dan limbah rumah tangga, aktivitas transportasi laut dan aktivitas perbaikan kapal laut.

Menurut $\mathrm{Yu}$ et. al (2010) Pergerakan logam serta ketersediaannya (bioavailability) di lingkungan perairan sangat dipengaruhi oleh bentuk dan tipe perikatan logam tersebut. Sedimen yang merupakan tempat akhir senyawa di lingkungan perairan sangat memegang peranan penting dalam menentukan bentuk-bentuk logam di perairan.,logam di sedimen bias berada dalam berbagai bentuk dan perikatan, antara lain, sebagai ion bebas dan berikatan dengan karbonat, logam bentuk ini disebut sebagai logam yang sangat labil sehingga mudah lepas keperairan serta mudah diserap oleh organisme (bioavailable). Kehadiran logam di sedimen, bisa memberikan dampak negatif pada biota bentik dan biota lainnya pada rantai makanan. 


\section{Metode Penelitian}

\subsection{Lokasi Penelitian}

Pengambilan sampel sedimen dilakukan pada daerah sekitar perairan pelabuhan kapal barang Talumolo di Kota Gorontalo sedangkan pengujian konsentrasi logam berat kadmium (Cd) pada sedimen dilakukan di Laboratorium Kimia Fakultas MIPA Universitas Negeri Gorontalo (UNG).

\subsection{Tahapan Penelitian}

\section{Persiapan alat dan bahan}

Tahap awal yang dilakukan dalam persiapan alat dan bahan yang di gunakan dalam pengambilan sampel sedimen di daerah sekitar perairan pelabuhan kapal barang Talumolo Kota Gorontalo yaitu, perahu, pipa paralon ukuran 4 inci, botol plastik, cool box, es batu.

2. Pengambilan sampel

Pengambilan sampel pada dasar perairan di tiga titik yang berbeda tapi masih di daerah sekitar perairan pelabuhan kapal barang Talumolo Kota Gorontalo. Penentuan titik pengambilan sampel ditentukan berdasarkan keberadaan limbah rumah tangga dan limbah industri dan penentuan lokasinya yaitu:

Titik 1: Muara Sungai Bone (daerah transportasi laut/ industri dan pemukiman)

Titik 2 : Pelabuhan Kapal Talumolo (daerah transportasi laut)

Titik 3 : Perairan Laut (daerah yang masih dekat dengan daerah industri dan pemukiman).

Sampel sedimen diambil dengan cara membenamkan pipa paralon dengan kedalaman $30 \mathrm{~cm}$ pada sedimen, kemudian pipa paralon tersebut di angkat secara perlahan-lahan, dan sampel sedimen dimasukan ke dalam botol sampel. Setelah itu, botol sampel sedimen dimasukan ke dalam cool box yang telah berisi es batu.

\section{Pengujian Kadar Kadmium (Cd)}

Prosedur Kerja Pengujian Kadmium (Cd) SNI 06-6989.16-2004) Mengeringkan sampel sedimen kemudian sampel sedimen ditimbang sebanyak 0,5 gr. Mengasamkan sampel sampai $\mathrm{pH}<2$ dengan HNO3 Endapan sampel, pipet $100 \mathrm{ml}$ sampel yang diasamkan ke dalam gelas piala $150 \mathrm{ml}$ tambahkan $50 \mathrm{ml}$ HNO3 p.a. dan batu didih kemudian uapkan di atas pemanas listrik sampai larutan jernih dan volumenya kira-kira $10 \mathrm{ml}$ sampai $20 \mathrm{ml}$. Sampel di pindahkan kedalam labu ukur $100 \mathrm{ml}$, dinginkan dan tambahkan air bebas logam yang mengandung HNO3 (1,5 ml) sampai tanda garis. Memeriksa larutan standar dan sampel menggunakan SSA Tungku karbon. 
Data yang diperoleh dianalisis secara deskripsi dengan membandingkan dengan standar baku mutu yang telah ditetapkan oleh Dapartment of Conservation and natural Resources Melbourne, Australia, 2004 (G.J Febris dan G.F Wagner, dalam Fasmi Ahmad ) dan baku mutu Dutch Quality Standars for Metals in Sedimen (IADC/CEDA 1997 dalam Dani 2012).

\section{Hasil dan Pembahasan}

Konsentrasi logam berat kadmium (Cd) pada sampel sedimen di daerah sekitar perairan pelabuhan kapal barang Talumolo Kota Gorontalo terdapat pada Tabel 1.

Tabel 4. Hasil Uji Kadmium (Cd) pada sedimen sekitar di pelabuhan Talumolo Provinsi Gorontalo.

\begin{tabular}{cccc}
\hline $\begin{array}{l}\text { Titik Pengambilan } \\
\text { Baku Mutu }\end{array}$ & Konsentrasi Kadmium (Cd) & Standar \\
\cline { 3 - 4 } Sampel & & $\mathbf{1}$ & $\mathbf{2}$ \\
Titik 1 & (ppm) & & \\
Titik 2 & 0,2027 & 1 & 0,8 \\
Titik 3 & 0,3229 & & \\
\hline
\end{tabular}

Sumber : (1) Dapartment of Conservation and natural Resources Melbourne, Australia, 2004 (G.J Febris dan G.F Wagner, dalam Fasmi Ahmad(2) Standars For Metals in Sediment, IADC/CEDA, (1997) dalam Dani intan C.(2012)

Berdasarkan Tabel 1, maka diketahui bahwa konsentrasi kadmium (Cd) pada sedimen di daerah sekitar Perairan Pelabuhan Kapal Barang Talumolo Kota Gorontalo yang tertinggi pada titik 2 yaitu sebesar 0,3229 ppm dan terendah pada titk 1 sebesar 0,2027 ppm. Tingginya konsentasi Kadmium (Cd) pada sedimen pada titik 2 diduga diakibatkan oleh limbah yang berasal dari aktivitas perkapalan di pelabuhan tersebut sehingga memicu adanya pencemaran logam berat dan tingginya limbah rumah tangga yang diakibatkan oleh padatnya pemukiman yang berada di sekitar perairan. Pembuangan limbah industri secara terus-menerus tidak hanya mencemari lingkungan peairan tetapi menyebabkan akumulasi logam berat dalam sedimen dan biota perairan (Nordic, 2003). 
Standar maksimum kadar logam berat kadmium $(\mathrm{Cd})$ yang diperbolehkan pada sedimen menurut baku mutu Dapartment of Conservation and natural Resources Melbourne, Australia, (2004) adalah sebesar 1 ppm dan baku mutu menurut Dutc Quality Standars For Metals in Sediment, IADC/CEDA, (1997) sebesar 0,8 ppm, mengenai konsentrasi logam berat yang ditoleransi keberadaannya dalam sedimen sekaligus melihat tingkat/level dari pencemaran logam berat yaitu khususnya logam berat kadmium $(\mathrm{Cd})$ dalam sedimen. Jika dibandingkan dengan standar baku mutu tersebut, maka konsentrasi logam berat kadmium (Cd) pada sedimen sekitar Perairan Pelabuhan Kapal Barang Talumolo Kota Gorontalo, masih berada di bawah standar baku mutu logam berat kadmium (Cd) pada sedimen dan dikategorikan bahwa kualitas sedimen di daerah sekitar Perairan Kapal Barang Talumolo Kota Gorontalo belum tercemar, tetapi sudah terkontaminasi oleh logan berat kadmium $(\mathrm{Cd})$.

Logam berat yang masuk ke dalam lingkungan perairan akan mengalami pengendapan, pengenceran dan dispresi. Kandungan logam berat yang menumpuk pada air dan sedimen akan masuk ke dalam sistem rantai makanan dan berpengaruh pada kehidupan organisme (Meador, 2005).

Keberadaan logam berat di lingkungan dapat berasal dari dua sumber. Pertama berasal dari alam dengan kadar di biosfer yang relatif kecil. Keberadaan logam berat secara alami tidak membahayakan lingkungan. Kedua, dari antropogenik dimana keberadaan logam berat tersebut diakibatkan oleh aktivitas manusia, misalnya limbah industri pelapisan logam, pertambangan, cat, pembuangan zat kendaraan bermotor, serta barang-barang bekas seperti baterai, kaleng dan lain sebagainya (Inswiasri, 2008).

Logam Cd dapat terabsorbsi oleh tubuh manusia tanpa ada yang menghalangi karena tidak ada mekanisme tubuh yang membatasinya. Sebagian besar Cd yang diabsorbsi tubuh akan dibuang keluar melaui saluran pencernaan. Keracunan kadmium dapat mempengaruhi otot polos pembuluh darah. Akibatnya, tekanan darah menjadi tinggi yang kemudian bisa menyebabkan terjadinya gagal jantung. Ginjal pun dapat rusak dari keracunan Cd (Darmono, 2001).

Hasil pengukuran parameter kualitas perairan di Pelabuhan Talumolo Kota Gorontalo dari setiap titik pengambilan sampel sedimen dengan Nilai Salinitas yang di peroleh yaitu berkisar 32-35\%o, nilai salinitas ini masih dalam keadaan baik untuk perkembangan biologis biota laut di perairan dimana kisaran normal dari salinitas yaitu 30-35\%0. Oksigen terlarut berkisar antra 4,2-5,2, dan pengukuran $\mathrm{pH}$ yaitu sekitar 6,5-7,2, nilai ini masih berada pada kadar alamiah untuk perairan laut yakni 6,5-8. $\mathrm{pH}$ berpengaruh terhadap toksitas suatu senyawa kimia, seperti logam berat kadmium (Shindu, 2005), sedangkan pengukuran suhu yaitu dengan kisaran sekitar $26^{\circ} \mathrm{C}-29^{\circ} \mathrm{C}$, suhu ini 
masih optimal bagi kehidupan perairan organisme dengan kisaran normal $25^{\circ} \mathrm{C}-35^{\circ} \mathrm{C}$.

Menurut Nybakken (1992) bahwa suhu air sangat menentukan aktivitas biologis yang terdapat di dalam air dan keaktifinya, suhu juga berpengaruh terhadap kecepatan reaksi kimia dan kelarutan gas-gas dalam perairan. Waykar, et.al (2012) menyatakan bahwa peningkatan suhu perairan cenderung menaikan akumulasi logam berat. Logam dalam air cenderung akan membentuk ikatan dengan bahan organik ataupun bahan anorganik.

\section{Kesimpulan}

Berdasarkan ahsil penelitian, maka dapat disimpulkan bahwa konsentrasi logam berat kadmium (Cd) pada sedimen di daerah sekitar Perairan Pelabuhan Kapal Barang Talumolo Kota Gorontalo yaitu :

1. Konsentrasi tertinggi pada titik 2 (Sedimen sekitar Pelabuhan) sebesar 0,3229 ppm, dan terendah pada titik 1 (muara sungai Bone) sebesar $0,2027 \mathrm{ppm}$.

2. Berdasarkan standar baku mutu Dapartment of Conservation and natural Resources Melbourne (2004) adalah 1 dan Dutch Quality Standars For Metals in Sediment, IADC/CEDA, (1997) yaitu 0,8 (ppm). Sedimen di daerah sekitar Perairan Pelabuhan Kapal Barang Talumolo Kota Gorontalo masih berada di bawah standar baku mutu, sehingga masih dikatakan belum tercemar, tetapi sudah terkontaminasi oleh logam berat kadmium (Cd).

\section{Daftar Pustaka}

Darmono. 1995. Logam dalam Sistem Biologi Mahkluk Hidup. UI press. Jakarta

2001. Lingkungan Hidup dan Pencemaran, Hubungannya dengan Toksikologi Senyawa Logam. UI Press. Jakarta.

Dahuri R, Rais J, Ginting SP, Sitepu MJ 1996. Pengelolaan Wilayah Pesisir dan Laut Secara Terpadu. Jakarta: Pradnya Paramita.

Hutagalung, H.P. 1994. Logam berat dalam lingkungan Laut. Pewarta oceana IX No. 1.

Inswiasri. 2008. Sumber-sumber Cadmium (Cd). Jurnal Ekologi Kesehatan VII(2): 775-785. 
Nowierski, M., G. Dixon, dan U. Borgman, 2002. Effect of water source on metaz bioavailability and toxicity from field collected sediments. Proceeding SETAC, Salt Lake City 16-20 November 2002.

Nordic. 2003. Cadmium Review. Denmark: Prepared by COWI A/S on behalf of the Nordic Council of Ministers.

Shindu, S, F.,2005, kandungan logam berat $\mathrm{Cu}, \mathrm{Zn}, \mathrm{Pb}$ dan Air, ikan nila (Oreochromisniloticus) dan ikan mas (Cyprinus carpio) dalam keramba jaring apung, jurusan manajemen sumberdaya perairan FIKP IPB Bogor.

Wardhana, Arya Wisnu.1995. Dampak Pencemaran Lingkungan. Andi Offest. Yogyakarta.

Yu, X., Y. Yana, W. Wang. 2010. The distribution and speciation of trace metals in surface sediments from the Pearl River Estuary and the Daya Bay, Southern China. Marine Pollution Bulletin 60 : 1364-1371 